\title{
The Liver Principle Active in Pernicious Anæmia
}

\author{
By Dr. Charles C. Ungley, Leverhulme Scholar of the Royal College of Physicians
}

$\mathrm{T}$ HE past decade has seen a complete change in our conception of the etiology of pernicious anæmia : formerly attributed to hæmolytic toxins, it is now regarded as a nutritional disorder. In 1926 Minot, Murphy and their co-workers demonstrated that liver was effective in pernicious anæmia ${ }^{1}$ and that the hæmopoietic response was quantitatively related to the amount of material administered ${ }^{2}$. Following the bone marrow studies of Peabody ${ }^{3}$, it appeared that a substance contained in liver allowed the maturation of megaloblasts to normoblasts and thus to adult red blood cells.

The true significance of the achlorhydria associated with pernicious anæmia soon became apparent. Fenwick ${ }^{4}$ in 1880 had observed the atrophic condition of the stomach in pernicious anæmia and noted the inability of the gastric juice to digest protein, but his conception of the disease as a nutritional disorder was lost sight of in an age when 'toxic theories' were in vogue. The classical experiments of Castle and his fellow workers $\mathrm{s}^{5,6,7,8,9}$ have shown that pernicious anæmia is a conditioned deficiency, based on a gastric defect. Material effective for blood regeneration in pernicious anæmia arises from the interaction of an intrinsic (gastric) factor present in normal gastric juice and an extrinsic (food) factor. The material which results from this interaction is absorbed from the intestine and stored in the liver and other organs.

Addisonian pernicious anæmia results from a deficiency of the gastric factor, but the syndrome of nutritional macrocytic anæmia may arise in other ways. Thus a diet deficient in the extrinsic factor is a chief etiological factor of the tropical macrocytic anæmias. Deficient absorption of preformed hæmopoietic material from the intestine or its destruction therein may contribute to the production of the macrocytic anæmia found in some cases of sprue, intestinal stricture, and multiple intestinal anastomoses. In pregnancy a latent partial deficiency may become manifest owing to the demand of the fœetus for hæmopoietic material. Defective storage of hæmopoietic material in the liver may account for the macrocytic anæmia sometimes found in hepatic cirrhosis.

The extrinsic factor is soluble in water and in 80 per cent alcohol, and is not destroyed by heating at $120^{\circ} \mathrm{C}$. for 5 hours. It is present in muscle meat, wheat germ $^{10}, 11$, rice polishings ${ }^{11}$, eggs ${ }^{12}{ }^{13}$ and possibly tomatoes ${ }^{14}$. Liver ${ }^{15}$ and liver extract" contain, in addition to fully formed active principle, a considerable amount of the extrinsic factor. Marmite (vegex), an extract derived from autolysed yeast, is a rich source of extrinsic factor ${ }^{17}$, but dried yeast is apparently inactive in this respect ${ }^{18}$. Ungley and James ${ }^{10}$ observed reticulocyte responses in some cases receiving alcoholic extracts of non-autolysed yeast as a source of extrinsic factor, and found that autolysis did not lead to noticeable increase in hæmopoietic effect. Groen ${ }^{14}$ finds that autolysis alone does not produce the factor, but has obtained positive results in four out of five cases with an extract of brewer's yeast, which after being autolysed by the addition of $\mathrm{HCl}$ and $\mathrm{NaCl}$ was heated in the autoclave. $\mathrm{He}$ suggests that extrinsic factor may arise from the hydrolysis of yeast proteins occurring at a high temperature in an acid medium. Strauss and Castle $^{17}$ originally suggested that the extrinsic factor might be vitamin $B_{2}$, but other workers ${ }^{10,14,18} 19,20$, 21 have been unable to identify it with any known portion of the vitamin B complex.

The gastric or intrinsic factor is a heat-labile substance extracted with difficulty from stomach tissue and is associated with the protein fraction of stomach press juice. According to Klein and Wilkinson $^{22}$, who call the substance hæmopoietin, it is probably a protein and is possibly enzyme. like in nature. Desiccated stomach, which prob. ably contains a mixture of intrinsic and extrinsic factors, is effective in daily doses of $30 \mathrm{gm}$. derived from about $200 \mathrm{gm}$. of fresh tissue. Wilkinson has obtained fractions effective in doses of $5 \mathrm{gm}$. daily. The work of Meulengracht ${ }^{24}$ suggests that in the pig the formation of the gastric factor takes place in the pyloric gland region, and also in the glands of Brunner in the duodenum, which are morphologically similar. On the other hand, the production of hydrochloric acid and pepsin is confined to the corpus region (Swedish terminology: fundus region) with its oxyntic and chief cells, this region being hæmopoietically inactive ${ }^{24}$.

The site of interaction of the intrinsic and extrinsic factors is unknown, but Castle ${ }^{25}$ suggests that at least one stage of the process of formation 
of the end-product active on the bone marrow takes place in the gastrointestinal tract presumably at or near neutrality. In vitro the resultant of this interaction is destroyed by heating to $70^{\circ}$ $80^{\circ} \mathrm{C}$. for an hour or by boiling for five minutes. The synthesis of a thermostable product identical with the liver active principle has yet to be accomplished.

Cohn, Minot and their co-workers ${ }^{26}$ obtained liver extracts active intravenously in doses as small as $0.025 \mathrm{gm}$. daily, but the earlier methods were not practicable for general use because of the large amounts of active material lost or destroyed in the process of fractionation. Using simpler procedures, Gänsslen ${ }^{27}$ and Castle $^{28}$ produced extracts which were effective parenterally in daily amounts derived from 5-20 gm. of liver. Given by injection, the extracts were $30-100$ times more effective than when administered orally. Attempts to isolate the liver factor have been hampered by the fact that the product is easily inactivated by chemical processes, and by the lack of a reliable non-clinical test for activity. Early steps were the removal of inert protein by coagulation with heat or alcohol and the precipitation of active material from the filtrate by phosphotungstic acid.

The product obtained from commercial liver extract by Dakin and West ${ }^{29}$ is of interest in view of its relative constancy of composition, the isolation of crystalline products of hydrolysis, and the apparent fact that clinical potency is constantly associated with the compound and is absent from preparations in which it has been either removed or chemically altered. Preliminary purification of the commercial liver extract was effected with calcium acetate in 75 or 80 per cent alcoholic solution. Thereafter almost the whole of the active material could be precipitated from the filtrate with Reinecke salt in acid solution. After decomposing the Reineckate the active material was repeatedly salted out with ammonium sulphate and afterwards with magnesium sulphate. Further fractionation was carried out with the aid of sodium chloride. The clinically potent products were light buff-coloured granular powders, the yield being approximately 1 per cent of the dry liver extract. Intravenously, doses of $75 \mathrm{mgm}$. have produced maximal reticulocyte responses. The material was soluble in water and dilute alcohol but insoluble in absolute alcohol and in ether. Hydrolysis yielded an aminohexose and a number of amino acids, namely, lysine, arginine, glycine, leucine, hydroxyproline, and aspartic acid. Pyrimidine or purine bases were absent. The substance was slowly decomposed by pepsin and more rapidly by erepsin. Pancreatic juice had no effect.
In pernicious anæmia during relapse, red marrow largely replaces the fatty tissue in the shafts of the long bones, the hyperplastic marrow being characterised by the presence of numerous megaloblasts. During remission the megaloblasts disappear and the bone marrow reverts to normal type. It seems that the liver principle aids the maturation of megaloblasts to normoblasts and thus to erythrocytes. At first many of the newly formed red blood cells escape into the circulation in a state of immaturity as reticulated cells. These reticulocytes, which usually number less. than two per cent before treatment, begin to increase rapidly about four days after the commencement of liver administration and reach a peak on the seventh to the tenth day. Up to a point the height of the reticulocyte response increases with the amount of active material administered, but even with maximal amounts the height of the peak is inversely proportional to the initial red blood cell count. From a red cell level of 1 million a peak of more than forty per cent may be expected, whereas with a level of two and a half millions the expected maximum is not more than fifteen per cent. When an adequate dose of liver extract is injected intravenously the rise of reticulocytes occurs earlier and reaches a higher level than when maximal doses of material are given daily by mouth.

The amount of material required to produce a maximal reticulocyte response or a maximal rate of increase of red cells, or to maintain a normal red blood cell level, is subject to marked individual variations and is influenced by factors such as age, arteriosclerosis and infections. There is thus no fixed dose, and each patient must be given sufficient material to suit his individual needs. The danger of over-dosage is negligible; even when very large amounts are administered parenterally over long periods of time the red blood cell count and hæmoglobin value rarely go much above the normal limits. During the reticulocyte crisis there is a marked increase in the urinary excretion of uric acid, possibly due to disintegration of red cell nuclei. Leucopenia disappears and the platelet count becomes normal. As the blood picture improves, the low protein and cholesterol values in the serum return to normal. Bilirubunæmia is abolished and the increased excretion of urobilin in fæces and urine ceases. Siderosis of the organs disappears, and indeed the rapid output of new red cells may exhaust the iron stores of the body, so that the colour index falls below unity, and a return to a normal blood picture is delayed. This can be overcome by the administration of iron.

During the remission there is a rapid increase of body weight due to fluid retention and to increased 
caloric intake ${ }^{30}$. The basal metabolic rate returns to normal or subnormal levels as the anæmia disappears ${ }^{30}$. Soreness of the tongue usually disappears during the first week of treatment. Regeneration of the atrophic lingual papillæ occurs in some cases. In the early stages of treatment, before the red blood cell count has risen significantly, there is a feeling of well-being and a return of appetite. At the same time there is a pink coloration of the face and extremities associated with dilatation of the skin capillaries. Gastro-intestinal symptoms such as flatulence, epigastric discomfort or pain, vomiting or diarrhœa frequently clear up during a liver-induced remission. In some cases, however, the administration of hydrochloric acid and pepsin is necessary to produce this result. The gastric defect which underlies the syndrome and which is accompanied by achlorhydria persists almost without exception. Nevertheless the fact that yeast preparations in large amounts will produce a hæmopoietic response of variable degree in many patients with pernicious anæmia suggests that the impairment of secretion of intrinsic factor is often relative rather than absolute $^{10}$. Castle ${ }^{9}$ has observed the recrudescence of intrinsic factor in a patient who originally secreted free hydrochloric acid without intrinsic factor in the gastric juice.

In a proportion of cases of Addisonian pernicious anæmia degenerative lesions are present in the brain, peripheral nerves and spinal cord, especially the latter. The incidence of subacute combined degeneration bears no relation to the severity of the blood dyscrasia, and may occur without anæmia. Relapses and remissions are frequent in pernicious anæmia, but in the absence of treatment the spinal cord condition is progressive. For amelioration of the neurological condition much larger doses of potent material may be required than are necessary to bring about a remission of the anæmia. In a recent series of 31 cases treated intensively for many months with liver extract intramuscularly ${ }^{31}$ we found that the degree of neurological improvement showed little or no correlation with age, initial anæmia or final bloodcounts, and depended less upon severity than upon duration. Eighteen patients with difficulty in walking for under one year improved, however severe the initial disability, whereas six long standing cases with an average duration of five years showed little change. Paræsthesiæ, dysfunction of the hands, sphincter disorders, mental disturbances, inco-ordination and impaired joint sense improved fairly consistently; impaired vibration sense and hypoæsthesia less so. Absent knee- and ankle-jerks often returned; increased jerks altered less frequently. Extensor plantar responses became flexor in six instances. Many patients who before treatment were completely bedridden and unable to stand regained more or less completely their ability to walk.

It is probable that subacute combined degeneration like pernicious anæmia itself is the result of a nutritional deficiency conditioned by a gastric defect. The substance necessary for the nutrition of the nervous system is possibly distinct from the hæmopoietic principle, arising in a similar way from the interaction of two factors, extrinsic and intrinsic. An investigation of the dietaries of cases of pernicious anæmia has shown no differences between those with and those with. out spinal cord degeneration ${ }^{10}$. On the other hand, there are certain facts which suggest that there is an intrinsic difference and that the gastric juice in cases of subacute combined degeneration lacks a factor distinct from "hæmopoietin" and for which Hurst ${ }^{32}$ suggests the name "neuropoietin".

In Addisonian pernicious anæmia, where defect in gastric secretion is marked, the incidence of subacute combined degeneration reaches $30-40$ per cent. In pernicious anæmia associated with polyposis of the stomach the incidence may be even higher ${ }^{33}$. In marked contrast in this respect are the tropical macrocytic anæmias and those macrocytic hyperchromic anæmias occurring in sprue, cœliac disease and pregnancy, in which factors other than gastric defect (for example, deficient diet, poor absorption, demands of the fœtus) are largely responsible for the deficiency of hæmopoietic principle. In these cases free hydrochloric acid is often present in the gastric juice, the response to extrinsic factor alone (as Marmite) is usually excellent, and subacute combined degeneration is extremely rare.

It has been suggested that the lesions in the nervous system in pernicious anæmia are due to deficiency or poor utilisation of vitamin A (Mellanby) ${ }^{34}$, vitamin $B_{1}$ (Gildea, Kattwinkel and Castle) ${ }^{35}$ or iron (Sargant) ${ }^{36}$, but the results obtained therapeutically with these sub. stances have been disappointing. There is no conclusive evidence that any material lacking the characteristic effect of liver upon hæmopoiesis in pernicious anæmia can arrest the progress or influence the course of. subacute combined degeneration.

The isolation of the hæmopoietic liver principle in a pure form would be an important step towards the solution of the problem. Up to the present, tests with liver extracts prepared in a variety of ways have failed to demonstrate any lack of parallelism between hæmopoietic potency and neurological effect. Should the highly-purified product prepared by the method of Dakin and West prove to be as effective in subacute combined 
degeneration as our preliminary observations would suggest, the hypothetical cord factor, if not identical with the hæmopoietic liver principle, must at least be closely allied to it chemically.

${ }^{1}$ G. R. Minot and W. P. Murphy, J. Amer. Med. Assoc., 87, 470-476; 1926 .

${ }^{2}$ G. R. Minot, E. J. Cohn, W. P. Murphy and H. A. Lawson, Amer. J. Med. Sci., 175, 599-622; 1928.

${ }^{3}$ F. W. Peabody, Amer. J. Path., 3, 179-202 ; 1927.

'S. Fenwick, "On Atrophy of the Stomach and on Nervous Affections of the Digestive Organs". (London: J. and A. Churchill, 1880.)

${ }^{3}$ W. B. Castle and E. A. Locke, J. Clin. Invest., 6, 2-3; 1928.

W. B. Castle, Amer. J. Med. Sci., 178, 748-764; 1929.

'W. B. Castle and W. C. Townsend, Amer. J. Med. Sci., 178, 764$777 ; 1929$.

${ }^{8}$ W. B. Castle, W. C. Townsend and C. W. Heath, Amer. J. Med. Sci., 180, 305-335; 1930.

W. B. Castle, C. W. Heath and M. B. Strauss, Amer. J. Med. Sci., 182, 741-764; 1931.

${ }^{10}$ C. C. Ungley and G. V. James, Quart. J. Med., 3, 523-548; 1934.

${ }^{11}$ W. B. Castle, Ann. Int. Med., 7, 1-5; 1933.

${ }^{12} \mathrm{~K}$. Singer, Wien. klin. Wehnschr., 45, 1063-1064; 1932

${ }^{13}$ D. K. Miller and C. P. Rhoads, New Eng. Med. J., 211, 921-924; 1934.

"J. Gröen, "Klinisch en experimenteel onderzock over anaemia perniciosa en voorwaardelijke deficientie". (Amsterdam: Scheltema et Holkema's Bockhandel, 1935.)
${ }^{15}$ F. Reimann, Med. Klin., 27, 880-881; 1931.

16 P. J. Fouts and L. G. Zerfas, J. Amer. Med Assoc., 101, 188$192 ; 1933$.

${ }_{17}$ M. B. Strauss and W. B. Castle, New Eng. J. Med., 207, 55-59; 1932

${ }^{18}$ L. Wills, Lancet, 1, 1283-1286 ; 1933.

10 L. Wills and A. Naish, Lancet, 1, 1286; 1933.

${ }^{20} \mathrm{~F}$. Diehl and J. Kuhnaü, Deutsch. Arch. klin. Med., 176, 149$153 ; 1933$.

${ }^{21}$ H. C. A. Lassen and H. K. Lassen, Amer. Med. Sci., 188, $461-$ $472 ; 1934$.

${ }^{22}$ L. Klein and J. F. Wilkinson, Biochem. J., 28, 1684-1692 ; 1934.

${ }^{23}$ J. F. Wilkinson, Proc. Roy. Soc. Med., 26 ; 632-634; 1933.

24 E. Meulengracht, Proc. Roy. Soc. Med., 28, 841-868; 1935.

${ }^{25}$ W. B. Castle, Science, 82, 159-164; 1935.

${ }^{26}$ E. J. Cohn, T. L. McMeekin and G. R. Minot, Trans. Assoc. of Amer. Physicians, 45, 343-349; 1930.

${ }_{27}$ M. Gänsslen, Klin. Wchnschr., 9, 2099-2102; 1930.

${ }^{28}$ W. B. Castle and F. H. L. Taylor, J. Amer. Med. Assoc., 96, $1198-1201 ; 1931$.

29 H. D. Dakin and R. West, J. Biol. Chem., 109, 489-522 ; 1935.

so J. Vaughan, Arch. Int. Med., 47, 688-689; 1931.

${ }^{31}$ C. C. Ungley and F. J. Nattrass : to be published.

${ }^{32}$ A. F. Hurst, Brit. Med. J., 2, 665-669; 1934.

${ }^{38}$ C. C. Ungley, Proc. Roy. Soc. Med., 28, 868-870; 1935.

s4 E. Mellanby, Edin. Med. J., 40, 197-222; 1933.

${ }^{36}$ E. F. Gildea, E. E. Kattwinkel and W. B. Castle, Nerv England J. Med., 202, 523-527; 1930.

36 W. Sargant, Lancet, 1, 230-232; 1932.

\section{F i r e - W a $1 \mathrm{k}$ ing}

\section{By Ernest S. Thomas}

SOME forty cases of the ember-walk and the $S$ stone-walk (to distinguish the two forms by these terms) selected from a larger number, collected from a wide range of accredited sources, were analysed for a paper I wrote for the Society for Psychical Research (published in the Proceedings in December 1934).

These narratives, with very few exceptions, are characterised by a lack of essential details, and that over-emphasis of the sensational aspects of the performance which seems inseparable even from some would-be scientific accounts. This lack of essential detail is not at first sight apparent, and it was not until I tried the ember-walk on a small scale myself in socks that these defects became apparent: namely, on a trench 9 feet long by 12 inches wide and some 6 inches deep filled with red hot, flameless, firestick-embers. I was able several times to take four steps in threadbare woollen socks (treading the embers five times) in 3 seconds without singeing, scorching or blistering $\rightarrow$ or discomfort at the time, but my foot-soles burned and tingled for several hours afterwards.

I attribute the immunity of my socks to their brief contact with the red hot coals and probably in part to the coating of ash, and that of my 'uncallused' feet to the woollen substitute for callus. I am, it should be stated, slight in build, of light weight (barely 9 stone) and tolerably agile.
Most of the observers of the ember-walk note the presence of ash, as well as of the great heat of the furnace walked upon. Regarding the latter, the fact that the surface coals are loosely packed over the furnace should not be lost sight of; so that the heat radiates out between the interstices of the cooler (because rapidly cooling) surface. Where the ash is not mentioned in accounts, there was clearly time for it to form before the walk began. In many cases (and one may assume it in all the important Indian cases) the legs of the walkers before the performance are wet (and doubtless cold) after bathing and/or immersion in turmeric water, and often coated with mud.

In a number of cases more or less rigorous ascetic training with meditation and concentration has been undergone, designed doubtless to enhance the powers of protective auto-suggestion. In several instances, the walkers bore silver skewers transfixing the dorsal muscles and other parts of their bodies, and one performer prior to the walk sat on a swing-seat full of 3-inch thorns; they pierced his flesh, but there was no bleeding. Dr. J. H. Hunt noted the almost total absence of bleeding when fakirs pierced their necks and abdominal muscles with rapiers ${ }^{1}$. Dr. William Brown noticed this also in the case of Rahma and Tara Bey ${ }^{2}$. Such contraction of the blood-vessels, through self-hypnotism, would tend to lower the temperature of the legs and feet (apart from the 